\title{
THE MISSING LINK IN THE HISTORY OF THE LOCKED INTRAMEDULLARY NAIL
}

\section{O ELO PERDIDO NA HISTÓRIA DA HASTE INTRAMEDULAR BLOQUEADA}

\author{
Flávio Pires de Camargo (In memoriam) ${ }^{1}$, Guilherme Pelosini Gaiarsa ${ }^{2,3}$ (1), Olavo Pires de Camargo ${ }^{1}$ (1), \\ Paulo Roberto dos ReIS ${ }^{2}$ (1), Jorge dos Santos Silva ${ }^{3}$ (i), Kodi EdSON KOJIMA ${ }^{3}$ (1)
}

1. Universidade de São Paulo, Faculdade de Medicina, Departamento de Ortopedia e Traumatologia, São Paulo, SP, Brazil.

2. Hospital das Clínicas da Faculdade de Medicina da Universidade de São Paulo, Instituto de Ortopedia e Traumatologia, Grupo de Reconstrução e Alongamento Ósseo, São Paulo, SP, Brazil. 3. Hospital das Clínicas da Faculdade de Medicina da Universidade de São Paulo, Instituto de Ortopedia e Traumatologia, Grupo de Trauma, São Paulo, SP, Brazil.

\section{ABSTRACT}

Femoral Shaft intramedullary nails were first described by the Aztecs in 16th century, but the modern use of intramedullary nails as the gold standard treatment for femoral shaft fractures began with Gerald Kuntcher in 1939. From the first Kuntcher's study in 1939, to the creation of interlocking nail, a long and some minor developments were described around the world. However, a major development is missing: the first nail to have a rotational and vertical stability locking system was described by Flavio Godoy Moreira, but was never published on an indexed journal for the correct historical reference. Level of Evidence V, Therapeutics Studies, Expert Opinion.

Keywords: Humans. Fractures, Spontaneous. Weight-Bearing. Fracture Fixation, Intramedullary. Femoral Fractures. Femur.

\section{RESUMO}

A história da haste intramedular bloqueada nas fraturas do fêmur se inicia com os Astecas no século 16, mas o uso moderno que a tornou o padrão ouro no tratamento destas fraturas se inicia com Gerald Kuntcher em 1939. Do estudo inicial de Kutcher até o desenvolvimento da haste bloqueada muitos pequenos desenvolvimentos foram descritos ao redor do mundo. Dentro deste desenvolvimento, a primeira haste a ter um controle vertical e rotacional foi descrito por Flavio Pires de Camargo, e nunca foi publicado em um jornal indexado que permita sua correta referência histórica. Nível de Evidência V, Estudos Terapêuticos, Opinião de especialista.

Descritores: Humanos. Fraturas Espontâneas. Suporte de Carga. Fixação Intramedular de Fraturas. Fraturas do Fêmur. Fêmur.

Citation: Camargo FP, Gaiarsa GP, Camargo OP, Reis PR, Silva JS, Kojima KE. The missing link in the history of the locked intramedullary nail. Acta Ortop Bras [online]. 2021;29(4):228-231. Available from URL: http://www.scielo.br/aob.

\section{INTRODUCTION}

The Aztecs were the first to describe the use of intramedullary nail to fix shaft fracture, in the $16^{\text {th }}$ century. ${ }^{1-3}$ There were also some descriptions of ivory nails in the end of $19^{\text {th }}$ century, ${ }^{4}$ but the history of modern intramedullary nailing of shaft fractures begins with $G$. Küntscher during the World War II. 5,6

Küntscher published the results of 39 cases in 1939 and, in 1947, another study with 107 war patients subjected to the treatment of femoral and tibia shaft fracture with intramedullary nail. ${ }^{2,4,6}$ At the same time, roughly 60 other surgeons around the word were also working on nailing research. ${ }^{1}$

After the arrival of the first American soldiers with German nails back from the war, the nail use expanded in US. The unlocked Küntscher nail had a good indication in simple type fractures at the isthmus of the femur and tibia, and bad results in non-isthmus (large canal) and comminuted fractures, with shortening and bad union. To expand the indication of nailing to complex fractures attempts to create axial and rotational control with the nailing has begun. ${ }^{1}$

Modny and Bambara ${ }^{7}$ in 1953, described a multiperforated nail with crossed screws to add axial and rotational control. Other authors worked in to ream the canal to insert larger nails.

In 1968, Küntscher discussed the "detensor" nail, soon called interlocking nail, with one crossing screw proximal and the other distal, to keep the length and rotation of the limb.

In the 1970s, the current design of nail with interlocking bolt was developed by a group of surgeons and spread all around the world. This review aimed to position in the history of the intramedullary nailing the innovative idea of Professor Flavio Pires de Camargo and his own design of a nail with a distal self-locking device to improve axial and rotational stability, by analyzing a published thesis with 240 patients in 1952 (Figure 1)

All authors declare no potential conflict of interest related to this article.

The study was conducted at Instituto de Ortopedia e Traumatologia do Hospital das Clínicas Da Faculdade de Medicina da Universidade de São Paulo (SP, Brazil). Correspondence: Guilherme Pelosini Gaiarsa. Rua Dr. Ovidio Pires de Campos 333, 3o andar, Cerqueira César, São Paulo, SP, Brazil. 05403010.guilherme.gaiarsa@gmail.com 
Even though Prof. Flavio's thesis is cited on a Küntscher's book ${ }^{8}$ as a reference, it was never published on an indexed journal to be easily accessible for research and citation.

A very similar system was described as Brooker-Willis nail, ${ }^{9-12}$ and one recent presentation on the EFORT congress refers to Prof. Flavio thesis pioneering system. ${ }^{10}$

Between August 1946 and December 1951, 240 fractures were treated with intramedullary nail in the Hospital das Clinicas da Faculdade de Medicina da Universidade de São Paulo.

OSTEOSSINTESE INTRAMEDULAR

\section{DE KÜNTSCHER}

CONTRIBUICCAO À TECCNICA E ESTUDO CRITICO BASEADO EM 240 CASOS

Figure 1. The thesis first page with the printed year (1952).

\section{DISCUSSION}

In Europe and North America, the number of scientific publications were increasing and intramedullary nails were a great area of development, as cited by Born. ${ }^{1}$ And in Brazil, the Instituto de Ortopedia e Traumatologia da Faculdade de Medicina da Universidade de São Paulo was a place for technique and implant development, counting on its own workshop to produce the created implants (Figure 2).

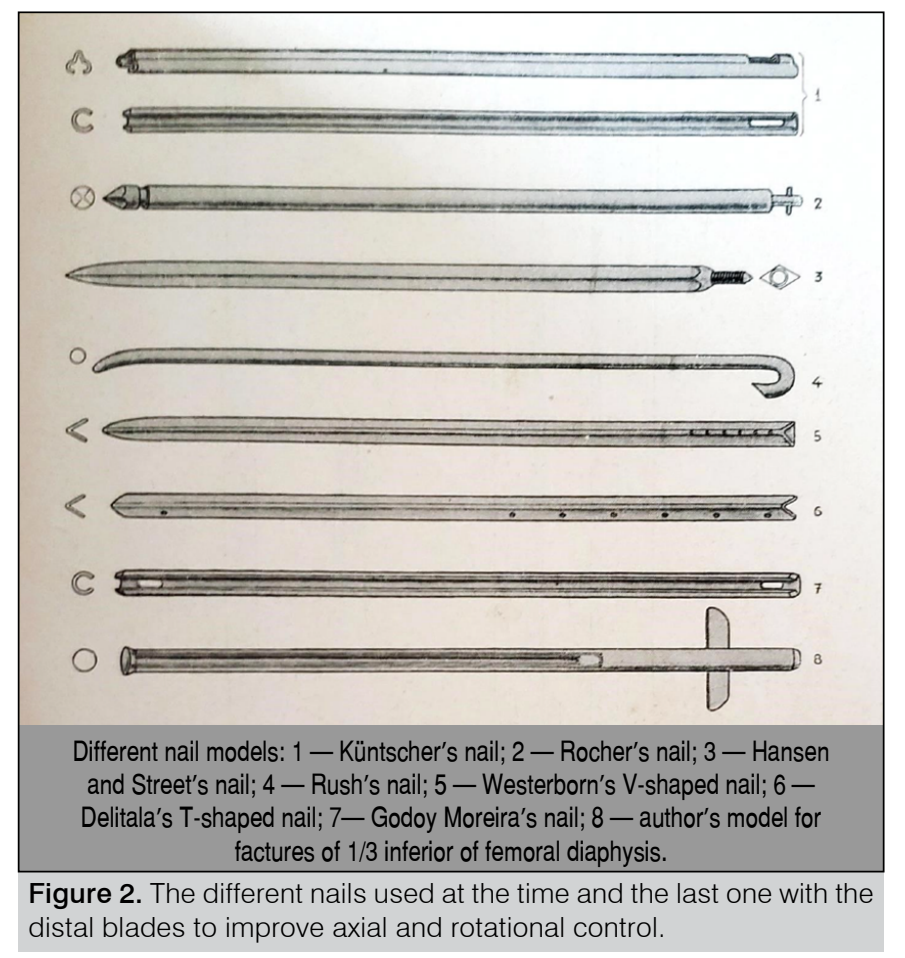

On the same period, however, the number of fresh femoral fractures on the clinic was 1269, and only 127 were treated with intramedullary nails. The use of intramedullary nails on every long bone is discussed on the thesis, therefore, this review focuses on the innovation on locking femoral nails.

The very first difference between Küntscher's technique and that described in the thesis is that the nails were made in an open focus style due to the strong fear of using X-Ray during the surgery (Figure 3).

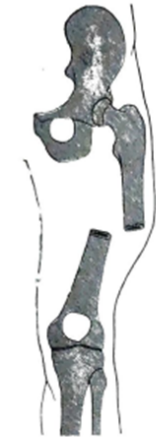

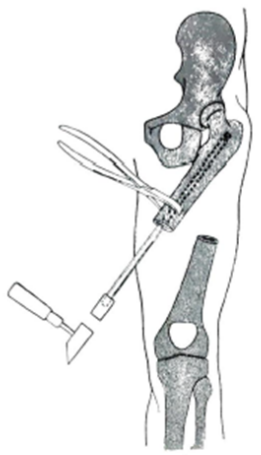

B

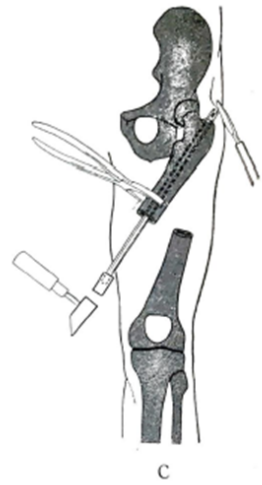

A - The surface fractures are isolated; $B-$ The proximal fragment is adducted and the nail introduction starts; $C$-The nail is introduced until its tip salient underneath the skin of the trochanteric region to open it.

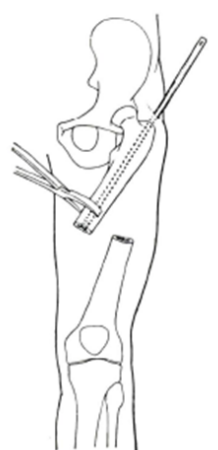

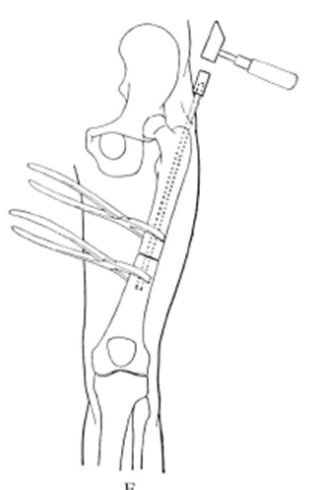

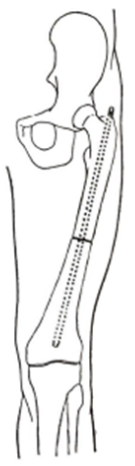

$\mathrm{F}$
$\mathrm{D}-$ The nail introduction in the proximal fragment is completed; $\mathrm{E}-$ Exact reduction of the fracture and nail introduction in the distal fragment; F-Operation finished.

Figure 3. The open technique to avoid X-Ray use. 
To make this technique simpler, both sides of the nail must have fit and threads compatible with the insertion device, so, for the retrograde insertion from the fracture site, the insertion device could be positioned on the other tip of the nail after the fracture reduction.

Another interesting reason to not perform the percutaneous technique is postponing surgery for some days after the trauma. The description is that the second hit to the patient could be fatal, and that waiting for some time before the surgery could be safer; however, it could cause shortening, and limiting the possibility of percutaneous reduction is probably a very early observation of this correct moment for surgery in the literature.

The real missing link is attributed by the author to the head of the department, Professor Godoy Moreira, who created a system with two blades on the tip of a metallic wire, that was inserted through the nail, and the blades opened when they found the threads on the distal part of the nail (Figure 4 and 5).
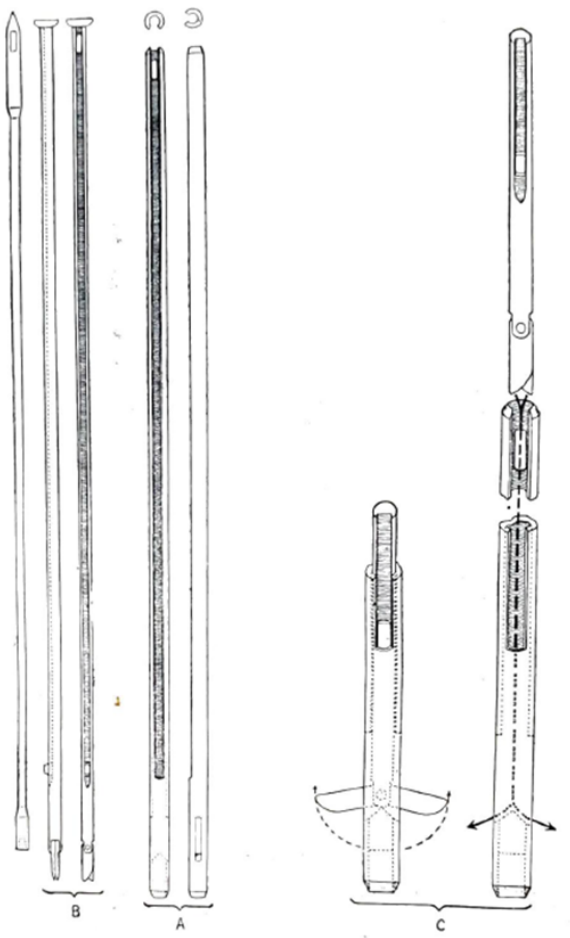

Küntscher's nail modification for the fracture of $1 / 3$ distal femur: $A-$ The nail in its two faces. Observe the modification on $1 / 3$ distal. B The stick is introduced inside of the nail. Observe in the distal end the two blades. $\mathrm{C}-$ With a simple mechanism the blades are opened and fixed in the spongy tissue or in the cortical internal face.

Figure 4. Schematic of the nail and the blade system.
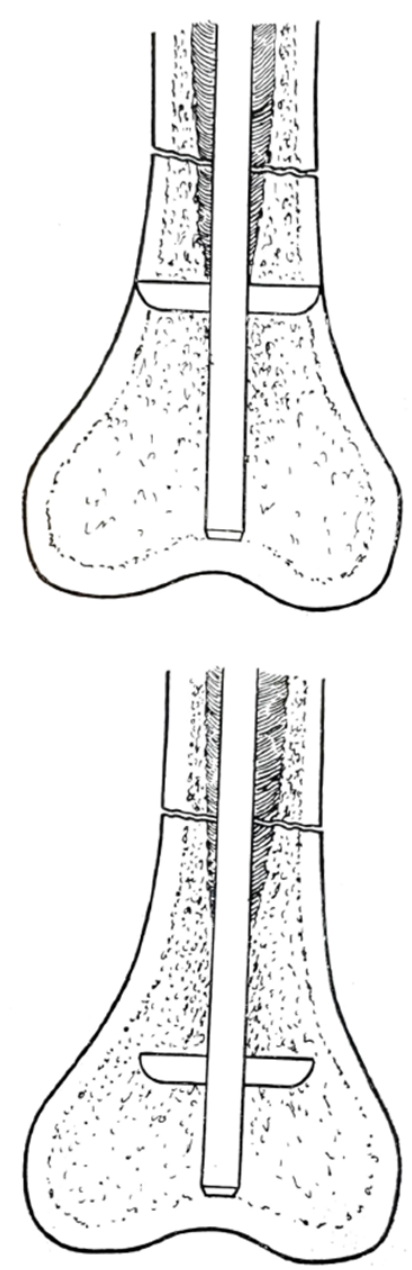

When the two blades are opened, they fix in the cortical internal face or in the osseous spongy tissue, then just low or lift the internal support. This detail must be determined before the operation.

Figure 5. Planning before the surgery to use the correct threads.

Although it was used on a small number of patients, only ten individuals at the time of the publication, good results are described, with rotational and angular control, bone healing and full weightbearing around 70 days (Figures 6 to 9).

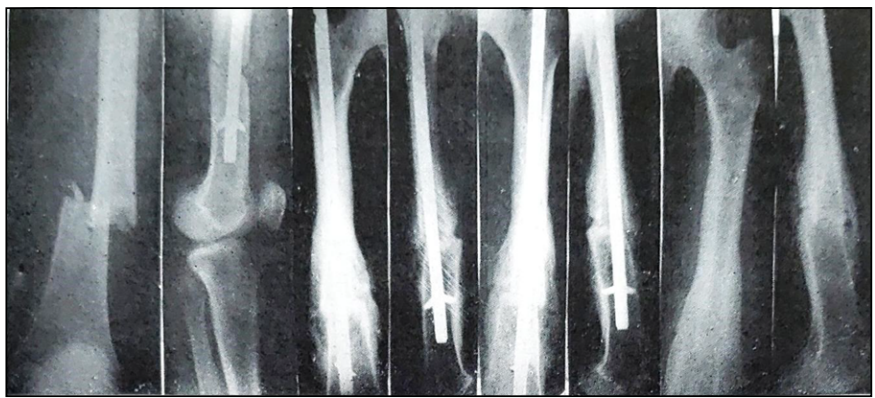

Figure 6. One of the blade cases. 


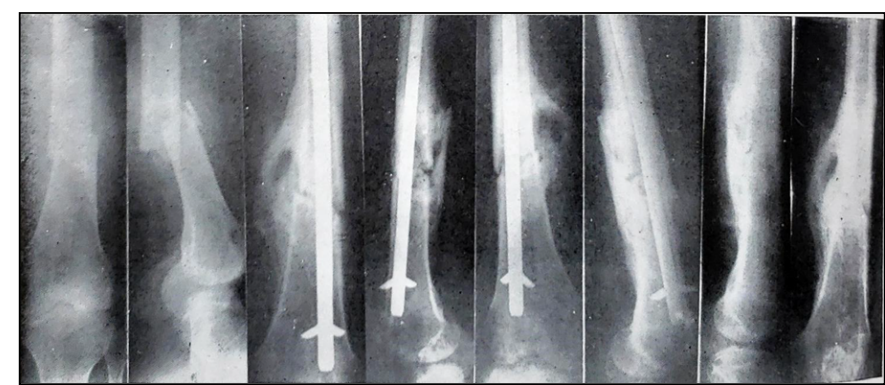

Figure 7. Fracture treated with the blade and after nail removal.

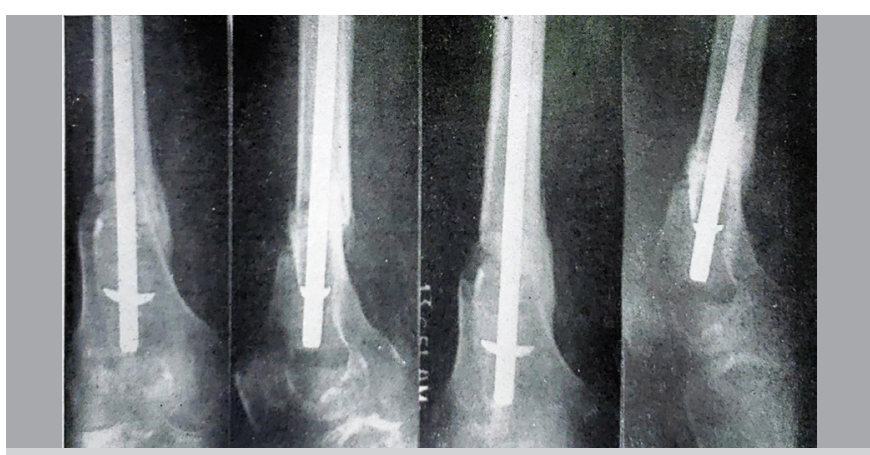

Figure 8. Another clinical example.

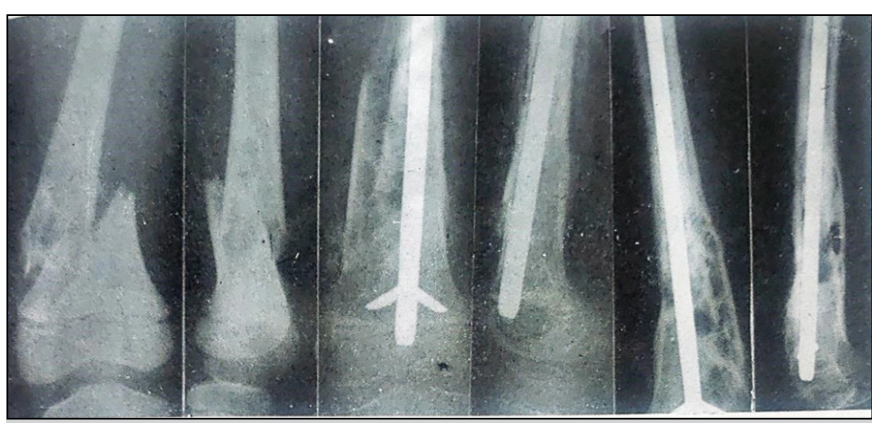

Figure 9. Pathological fracture.

The images were scanned from the original with permission, and used to bring this first description of a locking intramedullary nail back home, and pay tribute for those two pioneers of orthopedic surgery. The special Küntscher's nail was used not only on trauma, but also on some pathologic fractures to alleviate the pain and give comfort to the patients.

\section{CONCLUSION}

This thesis shows the Brazilian, and more specifically the IOTHC-FMUSP contribution for the history of locked intramedullary nails, and this data was not accessible on an indexed paper for research and citation.

AUTHORS' CONTRIBUTIONS: Each author contributed individually and significantly to the development of this article. FPC (in memoriam): writing of the manuscript; GPG: manuscript and literature review; OPC: data collection, bibliography, study concept, manuscript review; PRR: manuscript review; KEK: language adaptation.

\section{REFERENCES}

1. Born CT, Pidgeon T, Taglang G. 75 Years of Contemporary Intramedullary Nailing. J Orthop Trauma. 2014;28(8 Suppl):1-2.

2. Iotov A, Novkov H, Tanchev P. Brief history of intramedullary nailing. Ortop i Travmatol. 1999;35(2):152-61.

3. Pilih IA, Čretnik A. Historical overview and biomechanical principles of intramedullary nailing. Postgrad Sch Surg Tech. 2002;(Dec):13-8.

4. Vécsei V, Hajdu S, Negrin LL. Intramedullary nailing in fracture treatment : History, science and Küntscher's revolutionary influence in Vienna, Austria. Injury. 2011;42:S1-S5.

5. Küntscher G. The intramedullary Nailing of Fractures. J Orthop Trauma. 2014;28(8 Suppl):3-10.

6. Lindvall S. Küntscher's medullary nailing. Acta Chir Scand. 1950;100(5):522-9.
7. Modny MT, Bambara J. the Perforated Cruciate Intramedullary Nail: Preliminary Report of Its Use in Geriatric Patients. J Am Geriatr Soc. 1953;1(8):579-88.

8. Küntscher G. Praxis Der Marknagelung. Stuttgart: Friedrich-Karl Schattauer; 1962.

9. Brooker Jr AF. Brook-Wills nailingof femoral shaft fractures. Tech Orthop. 1988;3(3):41-6.

10. Taneja T, Mandal D, Sood L, MahaluxmiVala J, Natali C, Achan P,et al. Interlocked nailing of the femur with the brooker-wills nail: our experience. Orthop Proc. 2009;91-B(I Suppl):37.

11. Barrick EF, Mulhern PJ. Technical dificulties with the Brooker-Wills nail in acute fractures of the femur. J Orthop Trauma. 1990;4(2):144-50.

12. Devgan A, Marya K, Kundu Z, Jain S, Siwach R, Sangwan S. Critical evaluation of management of fracture shaft femur by Brooker Willis nail. Internet J Orthop Surg. 2002;1(2):1-7. 